\title{
И.И. Шеляпина
}

Аннотация. Статья знаколит читателя с инструлентали аксиологической лингволетодики, позволяющей включить подготовку к государственной итоговой аттестации в иеленаправленный, богатый подходали и методали процесс изучения русского языка как общенаиионального культурного фенолена. Целью статьи является описание эобобективных приелов работы с публицистическил текстол на уроке русского языка в 11 классе "Наполня будущее слыслали...". Выбор теоретических и опьтно-эксперилентальных летодов исследования связан с задачали систелатизации и классификаиии использованных на уроке заданий; моделирования учебного процесса на основе совреленного методического инструлента - лиговокультурологической характеристики текста; оценивания действий понилания публицистического текста. Авторол статьи утверждается эбббективность включения старшеклассников в разные виды деятельности (работа со словаряли и справочникали; лингвокультурологическая характеристика публииистического текста; написание публицистического текста по заданнылм паралетрал; выразительное публичное произнесение публииистического текста с иелью привлечения внилания и т.д.) на основе единого сиенарного построения урока. Связь телы урока с будущей профбессиональной деятельностью учащихся обеспечивает вовлеченность

1 Автор выражает благодарности:

Алевтине Дмитриевне Дейкиной - доктору педагогических наук, почетному профессору Московского педагогического государственного университета, основателю научной школы аксиологической лингвометодики, в русле которой автор строит свою научную работу, чьи труды служат импульсом для методического поиска автора и камертоном, с которым автор сверяет собственную педагогическую деятельность;

Ольге Николаевне Левушкиной - доктору педагогических наук, профессору кафедры методики преподавания русского языка, руководителю Центра русского языка и культуры им. А.Ф. Лосева Института филологии Московского педагогического государственного университета; автору методики лингвокультурологической характеристики текста, вдохновителю и научному руководителю автора в решении задачи применения лингвокультурологической характеристики публицистического текста в обучении русскому языку учащихся старших классов. 
старшеклассников в учебный процесс, субъективное переживание или содержания публицистических текстов и диалог с их авторали. Новизна статьи заключается в описании лотивирующей роли публицистического текста в обучении руссколу языку в старших классах. Теоретическая значилость статьи заключается в описании эбббективных способов деятельности, позволяющих моделировать учебнье ситуаиии на уроке русского языка с лингвокультурологической характеристикой текста. Практическая значилость статьи состоит в тол, что основнье ее положения логут найти широкое приленение в школьной практике в условиях внедрения ббедерального государственного образовательного стандарта среднего общего образования при подготовке $\kappa$ государственной итоговой аттестации. Представленный инструлентарий также адаптирован для обучения с приленениел дистаниионньх технологий.

Ключевые слова: аксиологический подход, обучение руссколу языку, публииистический текст, лингвокультурологическая характеристика текста, методический инструлентарий, приель работы с текстол.

\section{EFFECTIVE METHODS OF WORKING WITH PUBLICISTIC TEXT IN THE COURSE OF PREPARING STUDENTS FOR THE STATE FINAL CERTIFICATION IN THE RUSSIAN LANGUAGE}

\section{I.I. Shelyapina}

Abstract. The article introduces the reader to the tools of axiological linguamethodology, which allows including preparation for the state final certification in the purposeful, rich in approaches and methods process of studying Russian as a national cultural phenomenon. The aim of the study is to describe effective methods of working with the journalistic text in the 11th grade Russian lesson "Filling the future with meaning...". The choice of theoretical and experimental methods of research is connected with the tasks of systematization and classification of tasks used in the lesson; modeling of the educational process on the basis of the modern methodical tool - linguistic and cultural characteristics of the text; estimation of actions of understanding of the publicist text. The author of article asserts efficiency of inclusion of high school students in different kinds of activity (work with dictionaries and reference books; linguistic and cultural characteristic of the publicist text; writing of the publicist text on the set parameters; expressive public utterance of the publicist text with the purpose of attraction of attention etc.) on the basis of unified scenario lesson construction. Connection of a theme of a lesson with the future professional activity of pupils provides involvement of high school students in educational process, subjective experience of the contents of the publicist text and dialogue with their authors. The 
novelty of the research is to describe the motivating role of the journalistic text in teaching Russian in high school. The theoretical significance of the research is to describe effective ways of activity that allow modeling educational situations in the Russian language lesson with the linguistic and cultural characteristics of the text. The practical significance of the article is that the main provisions of the research can be widely applied in school practice in the context of the introduction of the Federal state educational standard of secondary General education in preparation for the state final certification. The presented tools are also adapted for distance learning.

Keywords: axiological approach, teaching the Russian language, journalistic text, linguistic and cultural characteristics of the text, methodological tools, methods of working with the text.

$\Pi$ одготовка к государственной итоговой аттестации по русскому языку в форме единого государственного экзамена, безусловно, является одним из важнейших направлений совместной работы учителя и ученика: обязательность и профильность предмета во многом определяют успех поступления выпускника средней школы в вуз. Несмотря на то, что современная методика преподавания русского языка располагает богатейшим инструментарием реализации различных подходов в обучении русскому языку с целью формирования языковой личности учащегося, на практике мы продолжаем сталкиваться с информационным стилем преподавания предмета, подменой последовательного изучения программы курса «натаскиванием» учеников на выполнение отдельных типов заданий и написание сочинения "по шаблону»: "НАатаскивание" на экзален не позволит в должной мере систелатизировать знания, развить личность ученика и решить его проблель в усвоении курса. В иелол следует говорить о необходилости слещения долинанты итогового контроля на непосредственно процесс обучения (развития) ученикал [1].

Ценностное отношение к языку как феномену национальной культуры, уникальному способу самовыражения, инструменту, с помощью которого человек обретает свободу мысли, позволит ученику выйти из плена «схем» и «штампов» и вести диалог с автором текста. Поэтому в каждый урок русского языка мы включаем инструменты аксиологической лингвометодики - актуального современного направления методики преподавания русского языка, обоснованного и развивающегося прежде всего в русле научной школы его основателя - Почетного профрессора Московского педагогического государственного университета Алевтины Дмитриевны Дейкиной [2].

Аксиологический подход, утверждающий, что весь учебный курс русского языка должна пронизывать идея особой, уникальной роли русского языка в жизни человека как воплощения культуры народа и его духовных ценностей, находится в неразрывной связи с когнитивным и 
деятельностным подходами, вне их применения он не может быть реализован в полной мере: следует «вернуть утраченные в образовании позииии и актуализировать идею создания “лыслящих школ”, выпускники которьх будут выходить в жизнь людьли, способньлии $\kappa$ творческой деятельности, способныли салостоятельно лыслить и принилить решения" [3, с. 206]. Именно эту идею мы кладем в основу целеполагания обучения русскому языку в старших классах: учащимися должна быть осмыслена особая ценность русского языка, который в своем богатстве и гибкости позволяет вступающему в жизнь молодому человеку осознанно говорить не только о настоящем, но и прогнозировать будущее, на основе идеалов и нравственных ценностей формулировать целевые установки саморазвития, взаимодействовать и коммуницировать с другими людьми, создавать творческие работы, характеризовать в лингвокультурологическом аспекте свою и чужую речевую деятельность, оценивать ее результаты.

В данной статье описано исследование эффрективности методического инструментария, положенного в основу урока развития речи в 11 классе, который должен стать для выпускников не просто еще одной предэкзаменационной тренировкой, а запоминающимся событием, наполненным ценностными смыслами и открытиями нового. Каждого одиннадцатиклассника на пороге взрослой жизни волнует выбор жизненного пути, будущей профессии, поэтому закономерна связь содержания урока (мы его назвали «Наполняя будущее смыслами...») с интерпретацией базового для русской культуры концепта «Труд», о чем подробно рассказано в наших статьях " $\mathrm{K}$ вопросу о связи концепта “Труд” с константами русской культуры “Свои” и “Чужие” в отечественной публицистике»; «"Наполняя будущее смыслами...": Методический комментарий к уроку развития речи в старшей школе» [4, с. 30-34; 5, с. 361-367]. Предлагая учащимся для работы на уроке публицистические тексты, мы исходим из того, что тексты публицистического стиля речи в большей степени, нежели тексты других стилей, нацелены на убеждение, мотивацию читателей и слушателей; их «однослойность» помогает избежать двусмысленности в толковании авторской позиции; публицистика оказывает эмоциональное воздействие и некий энергетический посыл, призыв к действию, что соответствует образовательным целям урока. В аналитических публицистических текстах ясно передается концептуальная информация, заключенная в словах — константах русской культуры, которые, входя в структуру языковой личности, становятся областями, сближающими автора и ученика. Если осмысление и переживание автором и читателем того или иного национально-культурного френомена происходит в одном русле, в одних границах, то, работая с текстом, ученик органично воспримет и присвоит мысли автора, вступит в диалог с ним и будет проводить сравнение и устанавливать связи между ключевыми понятиями. Поэтому важно сфрормировать у учащегося к моменту его выпуска из школы представления о концептах (константах культуры) и выработать у него определенное отно- 
шение к ним как непреложной ценности. Также важно научить ребенка видеть в тексте этот культурный концепт и понимать, как автор выражает свое отношение к нему.

Содержание урока, чередование в нем различных видов учебной деятельности, применение современного инструмента работы с текстом лингвокультурологической характеристики [6] позволят учителю достичь целевых установок, сформулированных в соответствии с требованиями ФГОС.

В структуре урока можно выделить несколько ключевых этапов. Эмоциональное включение учащихся и интерпретация темы урока (первый этап) организуются с помощью вопроса: чел ложно "наполнить" урок с названиел "Наполняя будущее сльслали...”?? Ответы учеников будут содержать прогнозы содержания урока и форм работы: на уроке с таким названием уместны создание устных и письменных сочинений рассуждений, организация дискуссии о будущем, о выборе жизненного пути, о судьбе родины и т.п.

Далее задается аксиологический вектор урока: одиннадцатиклассникам предлагается прочитать отрывок из текста С. Соловейчика «О пути жизни» [7, с. 40-41] и высказать свою точку зрения на жизненные цели, имеющие для них особую ценность; определить, что лежит в основе достижения этих целей.

Рассуждая, ученики приходят к выводу, что основой достижения жизненных целей является труд (пользуясь словарями, они подбирают наиболее полное определение этого понятия). Смысловые ориентиры на жизненном пути разные, но все связаны с деятельностью, трудом: «Труд требует выполнения работы и “усердия"... Стрелление человека направлено $к$ толу, чтобы встать над трудол, овладеть проиессол труда. В труде он все вреля узнает как салого себя, так и вещь: салого себя - в спонтанности примененной энергии, как фбизической, так и духовной; вещь - в ее сопротивлении этой энергии» [8].

Полезно заострить внимание учащихся вопросом: "Кел вы будете (хотите, планируете, собираетесь) работать?" (Что в этой фбразе связано со соберой постоянного, а что со соберой переленного?) В поле постоянного входит глагол "работать», не меняющий своего базового значения с течением времени. Значение местоимения «кем» - это категория непостоянного, зависящего от ценностей и возможностей субъекта деятельности; от условий внешнего мира; существующих профессий, устаревания одних и появления новых профессий и т.д.

Логическим завершением работы на этом этапе должна стать интерпретация темы урока: «наполнить будушее слыслами..." - значит, определить для себя жизненные иели, близкие и далекие; соборлировать идеальь и иенности; выбрать соберу деятельности; овладеть необходимьлии улениялии и т.д.

После того как учитель и ученики «договорятся» об общем понимании предмета разговора, можно переходить к следующему этапу урока - постановке творческой задачи и планированию аналитико-творческой деятельности учащихся.

Одиннадцатиклассникам предлагается кейс, работая над решени- 
ем которого, они смогут продемонстрировать и личные качества, и метапредметные и предметные компетенции.

Ученикал необходимо представить себя студентами - членами медиацентра современного университета. В университете есть фбакультеты (институты), которые ведут обучение по програмлам ппрофессий будущего». В ближайшую субботу состоится день открытых дверей, на котором надо провести агитационную калпанию: необходимо выступить перед абитуриентами с убеждаюшей речью на телу перспективности некоторых специальностей и подготовить текстовые материаль для инфбормационного буклета или листовки, чтобь привлечь салых талантливых и перспективных выпускников школ на свой фбакультет. Выступление не должно превышать 5 минут, а материаль для буклета (листовки) должны быть инфбормативными и не скучныли, соответствующили интересали выпускников.

Учитель объявляет названия $ф б a-$ культетов и профбессий из "Атласа новых профессий» [9], о которых члены университетского медиацентра должны рассказать будущим абитуриентам (полезно предложить избыточный список, чтобы у учащихся была возможность выбора).

Для продолжения работы учащиеся делятся на группы (объединяются в медиацентры фбакультетов) в соответствии с будущими профессиональными интересами; далее следует этап планирования работы в группах (для оценки промежуточных результатов учащиеся могут использовать форму чек-листа; предпочтительнее оценивать качество прохож-

Планирование и оценка качества выполнения работы в группах

\begin{tabular}{|l|l|l|}
\hline № & \multicolumn{1}{|c|}{ Основные этапы деятельности/ Текущие задачи } & $\begin{array}{c}\text { Оценка качества } \\
\text { выполнения (запол- } \\
\text { няется по заверше- } \\
\text { нии каждого этапа) }\end{array}$ \\
\hline 1. & $\begin{array}{l}\text { Распределиться по специальностям внутри факультета (института) в соответствии с будущими } \\
\text { профессиональными предпочтениями }\end{array}$ & \\
\hline 2. & Найти информацию о профессиях & \\
\hline 3. & Сделать вывод об общих признаках профессий будущего & \\
\hline 4. & Выполнить лингвокультурологическую характеристику текстов-образцов & \\
\hline 5. & Сформулировать общие требования к публицистическому тексту о профессии будущего & \\
\hline 6. & $\begin{array}{l}\text { Составить план собственного текста, подобрать заглавие, составить список ключевых слов, } \\
\text { определить особенности композиции и жанра, отобрать лексические, морфологические, } \\
\text { синтаксические средства. }\end{array}$ & \\
\hline 7. & Написать текст для публичного выступления & \\
\hline 8. & Адаптировать текст для включения в буклет (листовку) & \\
\hline 9. & Выступить с публичной речью на «Дне открытых дверей» & \\
\hline 10. & Дать оценку текста (работы группы) & \\
\hline 11. & Определить смысловые и ценностные результаты работы на уроке & \\
\hline
\end{tabular}


дения этапа развернуто, словесно, с указанием того, что получилось/не получилось и что нужно учесть/поменять в будущем) (см. табл. 1):

На этапе завершения общего образования учащиеся достаточно уверенно владеют навыками работы с разными источниками информации, поэтому с точки зрения развития когнитивности полезно предложить старшеклассникам раскрыть смысл не совсем знакомых и привычных названий профрессий (наприлер, ленеджер zеro waste, экопроповедник, экопродюсер, заповедный менеджер, дизайнер элоиий и т.д.). Результатом поиска информации о профессиях будущего в «Атласе новых профрессий» должен стать документ, содержащий словарные статьи о новых профрессиях:

\section{«Институт медиа и развлечений Спешиальности}

Дизайнер виртуальньх лииров: создает кониептуальные решения для виртуального мира: фбилособбия, законь природь и общества, правила социального взаилодействия и эконолики, ландшаббт, архитектуру, ошушения (в тол числе запахи и звуки), живой мир и соииальный мир.

Архитектор виртуальности: специалист по проектированию решений, позволяющих работать, учиться и отдьхать в виртуальной реальности. Разрабатыввает собот и оборудование, с учетом био- и психопаралетров пользователя (в тол числе под индивидуальный заказ).

Дизайнер элоций: специалист, создаюший элоциональный фбон контента с использованиел новых каналов доставки инфборлации, в тол числе и напрямую в мозг потребителя. Он управляет воздействием на органы чувств для того, чтобы в ходе потребления контента у пользователя возникали необходилье ошушения и элоции.

Продюсер сльслового поля: отвечает за борлирование общей картинь мира, в соответствии с которой будут строиться подвластные ему медиапотоки. Он управляет селекторали контента, которые фборлируют инборлационные потоки для пользователей в ралках заданной картинь мира, и осуществляет высокоуровневую настройку медиароботов. (Подобную роль в обществе играют "культурные сомельен из ролана Виктора Пелевина “S.N.U.F.F.”)» [10].

Необходимо сосредоточить внимание учащихся не только на интересных сведениях о необычных специальностях, но и направить их усилия на уяснение общих признаков профрессий будущего: ux сложность; метапредлетность; ориентацию на личность, индивидуальный подход; экологичность и энергосбережение; креативное начало и др.

Важную роль в обучении написанию текста заданного стиля и жанра играет разбор образцов. С этой целью старшеклассники индивидуально выполняют лингвокультурологическую характеристику публицистического текста об одной из совреленньх специальностей (методика лингвокультурологической характеристики подробно описана в исследованиях О.Н. Левушкиной [6]). Возможные варианты текстов: «Здоровое питание и повышение урожайности: Будущее в сельском хозяйстве - за микробиологией» [11]; «Топ профессий будуще- 
го: мнения экспертов (отрывок)» [12]; «В итальянской школе запустили учебный курс для старшеклассников о фрешн-блогерстве» [13]; “Сотрудник 3.0: языки, умение учиться и любовь»; «В союзе с роботом: какие специалисты будут нужны?» [14].

Результатом этого этапа работы на уроке становятся «Протоколы работы с текстом» каждого ученика:

Обобщение индивидуальных наблюдений оформляется в свод требо- ваний к выступлению на дне открытых дверей: небольшой объел текста, насыщенность интереснылии обактали, необычныци разворот тельи, элоциональность и экспрессивность речи и т.n.

Далее следует написание текстов выступлений и обсуждение их в группах; подготовка публичных выступлений и адаптация текстов для последующего включения в буклеты. Кульминацией урока становится $\mathrm{cu}$ -

Таблица 2

Протокол работы с текстом на основе лингвокультурологической характеристики

\begin{tabular}{|c|c|}
\hline Этапы характеристики текста & $\begin{array}{l}\text { Наблюдения, } \\
\text { выводы }\end{array}$ \\
\hline $\begin{array}{l}\text { В чем особенности формулировки заглавия текста? Как можно спрогнозировать содержание и идею текста по } \\
\text { заглавию? }\end{array}$ & \\
\hline Произошел ли эмоциональный отклик на текст: «зацепил» ли текст? какие эмоции вызвал? и т.п. & \\
\hline Какие цели стояли перед автором текста? & \\
\hline $\begin{array}{l}\text { Сформулируйте ценностные смыслы текста, связанные с общечеловеческими, общекультурными и } \\
\text { национальными ценностями }\end{array}$ & \\
\hline Какой жанр и стиль выбирает автор для достижения речевой задачи? & \\
\hline $\begin{array}{l}\text { Что лежит в основе композиции: } \\
\text { - общая характеристика предмета описания или впечатления от него-признаки предмета описания - общая } \\
\text { оценка предмета описания; } \\
\text { - завязка-развитие действия-развязка; } \\
\text { - тезис-доказательства-вывод; } \\
\text { - другое. } \\
\text { Аргументируйте свою точку зрения }\end{array}$ & \\
\hline Что можно сказать о типе (типах) речи? & \\
\hline Ключевые слова: их значение и роль в тексте & \\
\hline $\begin{array}{l}\text { Особенности лингвистики текста и ее связь с целями автора (своеобразие лексики, морфологические } \\
\text { особенности, причинно-следственная взаимосвязь предложений в тексте и их частей, роль изобразительно- } \\
\text { выразительных средств) }\end{array}$ & \\
\hline Роль концептов в тексте (при наличии) & \\
\hline $\begin{array}{l}\text { Какие культурные смыслы заключает текст? В чем автор видит культурное значение предмета описания } \\
\text { (обсуждения, изучения и др.)? }\end{array}$ & \\
\hline $\begin{array}{l}\text { Какие ассоциации возникают у автора в связи с предметом описания (обсуждения, изучения и др.)? } \\
\text { Какие ассоциации возникли у вас? }\end{array}$ & \\
\hline Сформулируйте собственное представление о смыслах текста и позиции автора & \\
\hline Выразите собственное отношение к смыслам текста & \\
\hline Выразите собственное отношение к позиции автора & \\
\hline Выразите свое отношение к ценностным смыслам данного текста & \\
\hline
\end{tabular}


туаиия "Дня открытыьх дверей" $u$ публичные выступления членов "медиацентров".

Завершается урок оценкой публичных выступлений и рефрексией: старшеклассники делятся впечатлениями об уроке, выражают степень удовлетворенности работой в группе; выражают произошедшие изменения во взглядах и компетенциях. В качестве домашнего задания учащимся предлагается создать проект буклета на основе написанных на уроке текстов или написать сочинение о своей будущей профессии.

Активное развитие электронного обучения и дистанционного образования, связанное с процессами персонализащии и информатизации, ставит сегодня перед методистом и учителем задачу создания универсального учебного контента, с которым можно работать как очно, в классе, так и опосредованно, дистанционно. С этой целью все материалы урока размещены для использования и тиражирования в общедоступной папке на платdopмe Google Диск (https://drive. google.com/drive/my-drive). Пользуясь предложенными материалами, учитель может их редактировать по свое- му усмотрению исходя из учебной и творческой задачи.

На рис. 1 представлен вид документов в папке урока русского языка «Наполняя будущее смыслами...» на Google Диске, к которому открыт совместный доступ учителя и учеников.

До начала урока учитель размещает в электронном журнале для каждого ученика ссылку на его рабочие материалы (https://drive.google. com/drive/folders/1UQBC4uj3c047yO4 0mnMjU4G3FdyY95Mo).

На рис. 2 представлено расположение в общей папке на Google Диске рабочих материалов всех учеников класса. Учитель присваивает каждому документу имя ученика и отправляет каждому учащемуся ссылку на его рабочие материалы. Совместный доступ редактирования позволяет учителю не только просматривать документы учеников, но и оставлять в них свои пометки.

Рабочие материалы каждого ученика содержат информацию и алгоритм действий, которому должен следовать ученик, чтобы переходить от индивидуальных заданий к групповой работе с документами, открытыми для совместного редактирова-

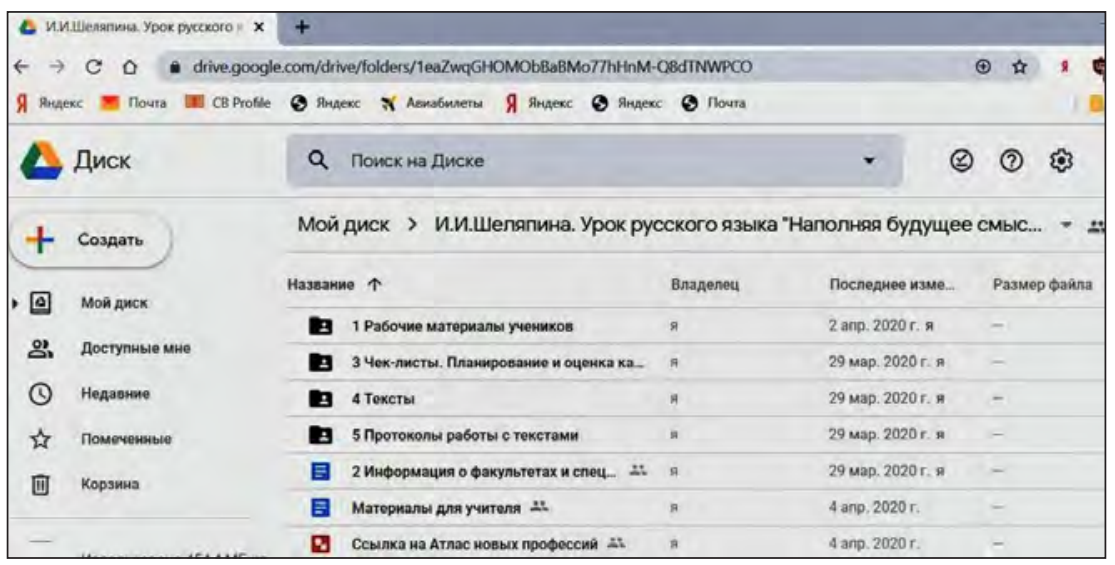

Puc. 1. Скриншот расположения документов в папке «Урок русского языка “Наполняя будущее смыслами....” на Google Диске 


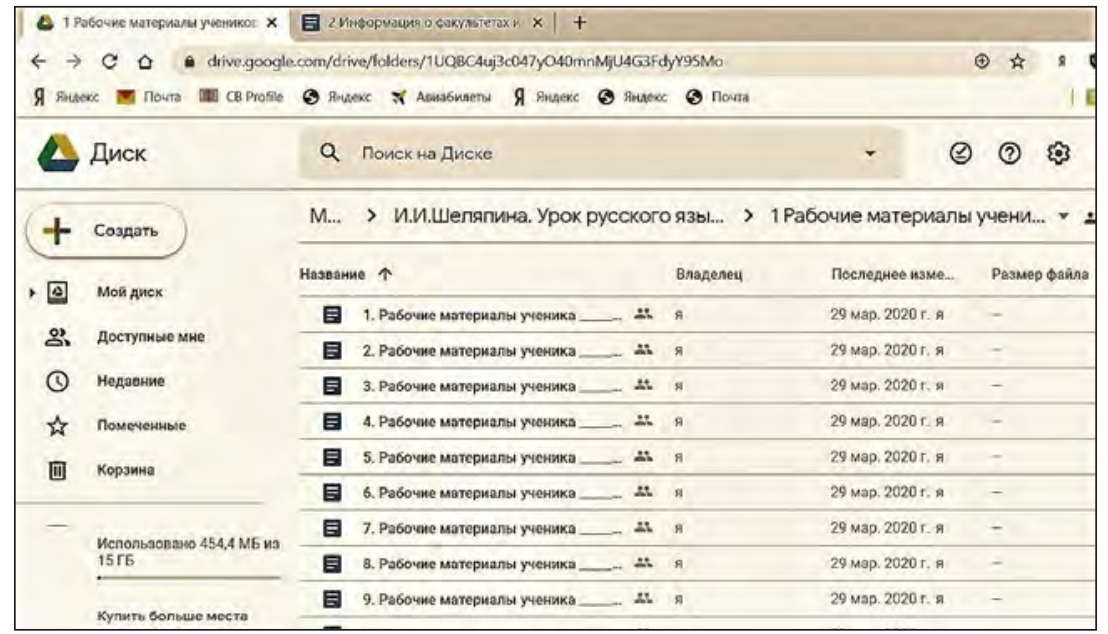

Puc. 2. Скриншот расположения документов в папке «1 Рабочие материалы учеников» на Google Диске

ния текста (https://docs.google.com/ $\mathrm{d}$ o $\quad \mathrm{c}$ u $\mathrm{m}$ e $\mathrm{n}$ t / d / $10 \mathrm{~W}$ lEWlp69Uqn46ta277 8Y4kNt1mTKpRWpt6bBsFep4/edit? usp=sharing).

Ниже приведен пример доступных для тиражирования рабочих материалов одного ученика, в которые учитель при необходимости может вносить свои коррективы:

\section{Дорогой одиннадиатиклассник!}

Сегодня Bы станете участникол урока «Наполняя будушее слиьслали...", который входит в телатический раздел "Публииистический стиль речи».

Вали предлагаются для работы индивидуальные задания, ответь на которье Вы будете вносить в Ваши рабочие материаль в специально отведенные леста, и задания для работь с общили докулентами, к которылл открыт доступ $y$ Ваших одноклассников и учителя.

Мьь очень надеелся, что этот материал положет Вал сфорлировать свой взгляд на будушую профбессию, по-новолу взглянуть на богат- ство и возложности русского языка. Желаел успеха и радости обретения новых знаний и новых сльслов!

\section{1. Постарайтесь сбборлулиро-} вать, чели можно "наполнить" урок с заглавиел "Наполняя будуиее сльслали...»?

Для продолжения размышлений прочитайте отрывок из «пушкинской проповеди» Симона Соловейчика «О пути жизни»:

"Путь жизни, длинныцй, трудныци, со многили печаляли и страданиями, человек не проходит, а совершает, свершает. Это только кажется: вот дорога, вот судьба, и человек шагает себе по судьбе-дороге, выполняя ежедневные свои задачи и задачки. Да нет же, все не так: путь жизни - это, конечно, и дорога, простираюшаяся не по полю, а во врелени, но путь жизни - это и дол, и дело, $и$ своего рода строительство, которое нал предстоит свершить $\kappa$ неизвестнолу нал сроку" [9, с. 40-41].

2. Назовите жизненнье иели, которые илеют для вас особую иенность: 
Что лежит в основе достижения жизненных целей?

(Возможный комлентарий учителя. Полностью согласны с Вами: слыслловые ориентиры на жизненном пути разные, но все они связаны с деятельностью, трудол.)

3. A теперь подулайте над вопросол: "Кел вы будете работать?». Что в этой ббразе связано со сфберой постоянного, а что - со сфберой переленного?

(Комментарий учителя. Вы правы. В поле постоянного входит глагол «работать», не меняющий своего базового значения с течением времени. Значение местоимения «кем» это категория непостоянного, зависящего от ценностей и возможностей субъекта деятельности; от условий внешнего мира; существующих профрессий, устаревания одних и появления новых профессий и т.д.)

4. Приходим к выводу: мы избежим неудач сами и поможем своим ровесникам избежать многих неудач на жизненном пути, если будем знать о профессиях, востребованных в то время, когда мы вступим во взрослую жизнь.
A как теперь Вы ответите на вопрос: что значит "наполнить будущее слыслали...»?

5. Дальнейшие задания Вы будете выполнять влесте с одноклассникали.

Познакольтесь с «легендой», которая положена в основу кейса:

Совсем немного времени осталось до того момента, когда Вы получите аттестаты и придете в приелную колиссию. Сегодня мы заглянем в будущее и представим, что Вы студентыь одного из салььх современных университетов, который осуществляет обучение специальностяли будущего. Перед Вали стоит задача провести агитационную кампанию, чтобы наибольшее количество выпускников захотело учиться иленно на Вашел фбакультете. (В рабочих материалах учеников дается детализация кейс-задания).

6. Для продолжения работь найдите в папке урока и откройте докулент № 2 "Инфбормация о фбакультетах и специальностях" (https://docs.google.co m/document/d/1VMci8jOVREwOYD rZRGMgfqAcl47TQkWujBjw1ItUBjk /

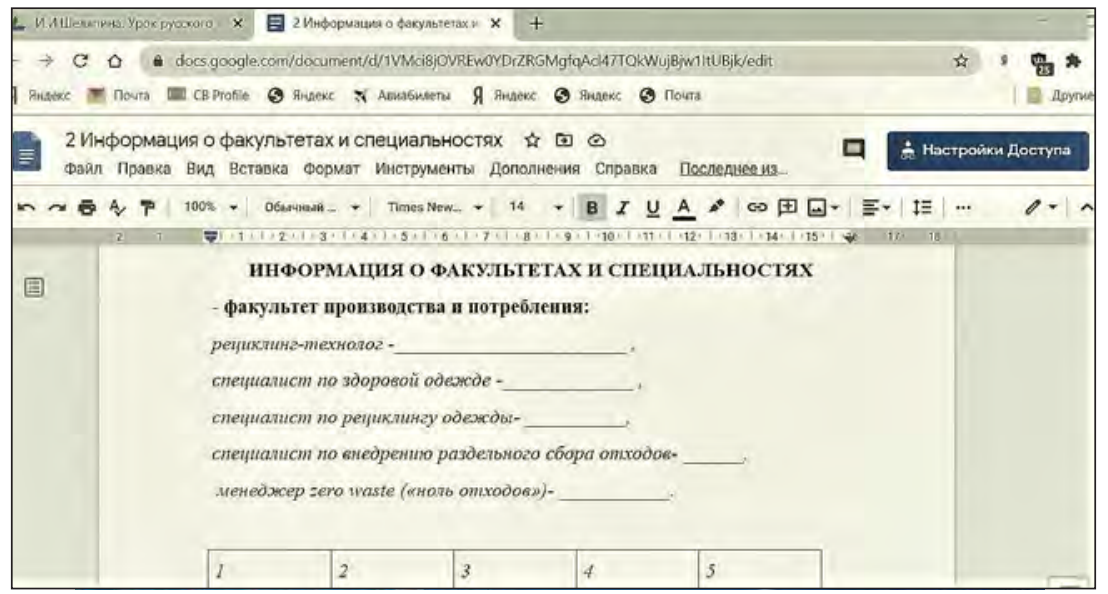

Puc. 3. Скриншот документа 2 «Информация о факультетах и специальностях» на Google Диске 
edit?usp=sharing). Выберите в соответствии с Вашили пробрессиональнылии интересали фбакультет и специальность, о которой бы Вы хотели узнать новое и рассказать. Впишите свое иля в пустую клетку таблицы. Постарайтесь не оказаться в одиночестве. Если медиацентр выбранного Вами фбакультета не сбормировался, впишите свое имя в группу, где уже есть Ваши одноклассники.

На рис. 3 представлен вид документа 2 «Информация о факультетах и специальностях» на Google Диске, к которому открыт совместный доступ учителя и всех учеников. В течение урока ученики будут искать в «Атласе новых профессий» информацию о профессиях будущего и вносить ее в этот документ. В результате работы у всех учеников класса будет полное описание каждой профессии.

Tеперь, когда ледиацентрь сборлированы, обратитесь $к$ расположеннолу в папке № 3 "Чек-листь. Планирование и оценка качества выполнения работы медиацентрали ббакультетов" (https://drive.google.com/drive/ folders / 1EWYA-Kgczq3SKWbz1bF7CN
WVdzkuNjRu? usp=sharing) чек-листу планирования и оченивания совлестной работы Вашей творческой группь.

В этот документ могут вносить записи все члены медиацентра. Не закрывайте документ до окончания работы.

Прежде чем Вы будете писать (рассказывать) о профессии будущего, надо как можно больше узнать о ней.

Для этого обратитесь по ссылке $\kappa$ «Aтласу новыцх nроббессий» (http:// atlas100.ru/) и внесите полученную инфбормацию о профбессии в документ № 2 "Инфбормация о фбакульmетах и специальностях" (https:// docs.google.com/document/d/1VMc i8jOVREwOYDrZRGMgfqAcl47TQkW ujBjw1ItUBjk/edit). B результате совместной работы класса Вы будете илеть полную инфборлацию о многих пробессиях будущего.

Еще раз внилательно прочитайте инборлиацию о профбесси$я x$ будущего и запишите их общие признаки. (Учителю важно проследить, чтобы ученики отметили такие признаки профбессий будущего, как сложность; экологичность и энергосбережение; мультиза-

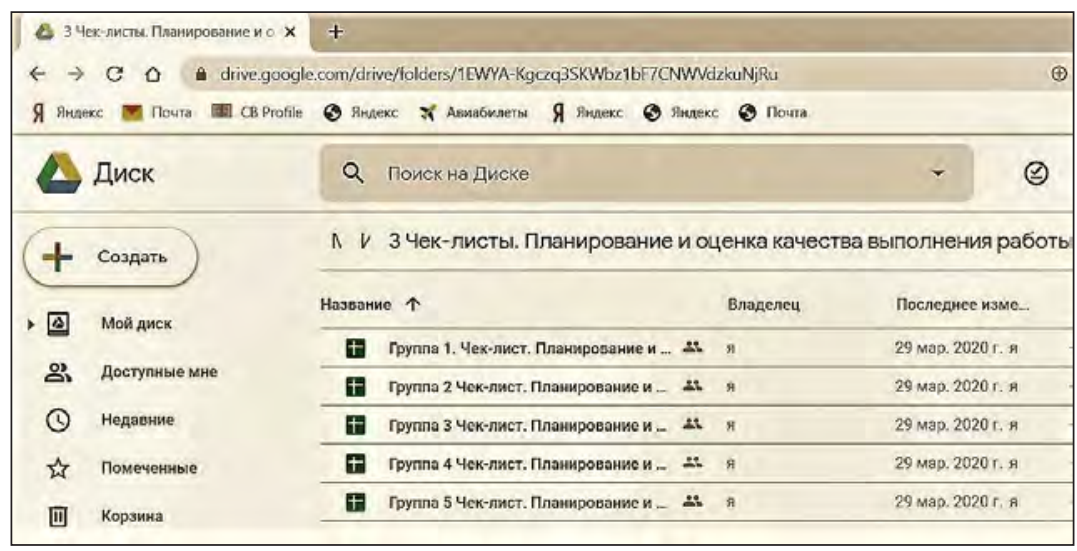

Puc. 4. Скриншот папки 3 «Чек-листы. Планирование и оценка качества выполнения работы медиацентрами факультетов» 
дачность и летапредлетность; ориентация на личность, индивидуальный подход; креативное начало и др.)

Необходимым этапом успешного выполнения задания является подготовка к написанию собственного текста.

Для этого познакомимся с некоторыми текстами СМИ и постараемся определить характерологические черты публищистических текстов на тему профессий и сфрер деятельности будущего. Откройте папку № 4 «Тексты» (https://drive.google.com/drive/fo lders/1mD1YxEeKc92Eq5NfEiLS4F 6Pje-IRxQn) и выберите текст под но- мером, который соответствует Вашему номеру в таблице участников медиацентра (документ № 2 «Инфрормация о фракультетах и специальностях»):

Прочитайте текст и выполните его характеристику, внося свои наблюдения в Протокол работы с текстом, который расположен в папке №5 (https://drive.google.com/drive/fold ers/1z_8Cr3iBif7pMTDq2H-1LJWeX J_4iL46?usp=sharing )

На рис. 7 «Скриншот Протокола работы с текстом» видно, что в результате одновременной работы с документом каждый ученик дает тексту лингвокультурологическую хара-

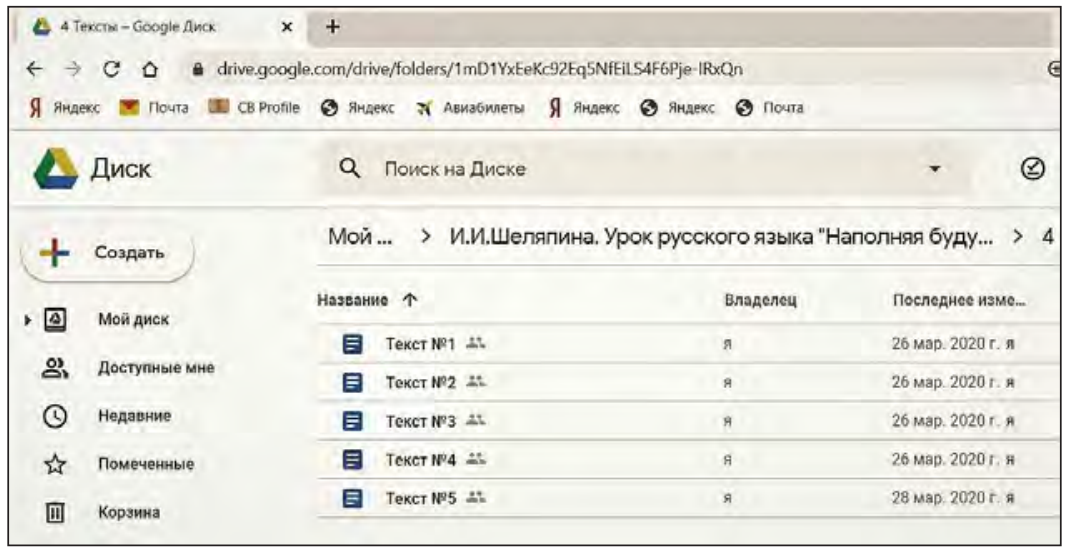

Puc. 5. Скриншот папки 4 «Тексты»

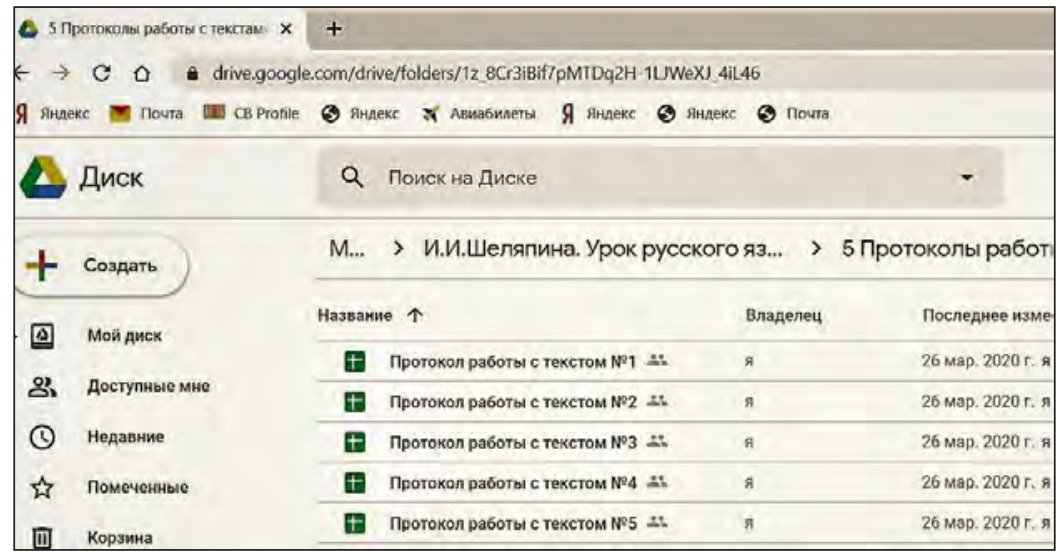

Puc. 6. (криншот папки 5 «Протоколы работы с текстами» 


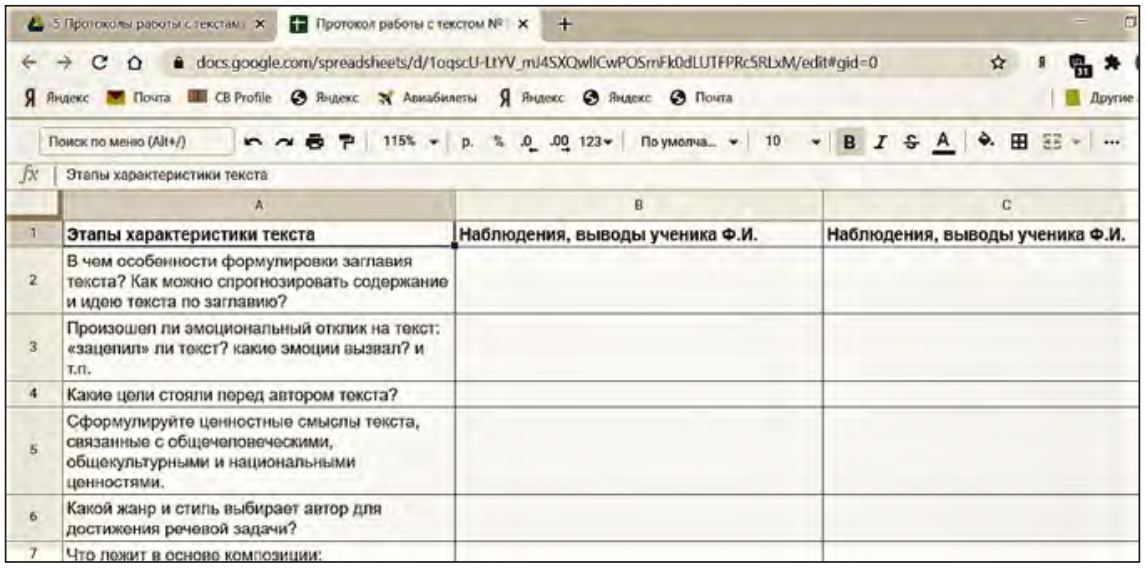

Puc. 7. Скриншот Протокола работы с текстом

керистику. В итоге ученики обогащают собственные наблюдения и оценочные суждения выводами своих одноклассников.

Теперь ложно обобицть свои наблюдения и сбборлулировать, какили чертали долюкен обладать публичистический текст на телу профбессии будущего, чтобы быть представленнылм на дне открытых дверей выпускникали и их родителял?

(Совет учителя. Во-первых, текст должен быть небольшого объема; вовторых, он должен «цеплять» - содержать интересные фракты, необычный разворот темы и т.п.; в-третьих, быть эмоциональным и экспрессивным; в целом же он должен обладать стилистическими характеристиками, позволяющими отнести текст к публицистическому стилю.)

Вся подготовительная работа выполнена, и значит, можно приступать $к$ написанию текста выступления на дне открытых дверей.

Если есть техническая возможность, произнесите свою речь вслух.

Поздравляем! Вы успешно справились со всеми заданиями. Подели- тесь своими впечатлениями от работы на уроке. Что получилось? Над чем интересно было размышлять? Что бы Вы хотели поменять? Какие открытия Вы сделали для себя, работая над материалом?

Предлагаем Вам дома поработать над проектом буклета на основе созданных на уроке текстов или написать сочинение о своей будущей профрессии.

Спасибо за урок!

На протяжении занятия учитель имеет возможность просматривать все документы и вносить в них свои комментарии. Если позволяют технические возможности, то участники урока могут подключиться к одной из программ видеоконференцсвязи (Skype, Zoom, Proficonf и др.), устно комментировать действия и смотреть видеовыступления друг друга; при отсутствии такой возможности учитель и ученики могут выкладывать видеоролики обращений и устных ответов, используя видеохостинг YouTube. Итогом урока станут творческие работы учащихся, доступные на Google Диске. 
Опыт проведения данного урока в очередной раз убеждает нас в том, что выведенный из рамок «схем» процесс подготовки к экзаменащионному сочинению может стать для старшеклассников запоминающимся, наполненным личностными смыслами событием.

Результаты нашего исследования (характеристики текстов, отчеты работы групп, творческие работы и устные ответы учащихся) позволяют судить об эфрфективности описанного методического инструментария. Системность подходов к содержанию и организации работы на уроке, прежде всего аксиологического, деятельностного и лингвокультурологического, обеспечивает формирование у учащихся языковой картины мира. В творческих работах одиннадцатиклассников прослеживается ценностное отношение к труду в целом как основе саморазвития и профессиям будущего, в частности, как основе прогресса; устанавливаются глубокие связи труда и культуры своего народа; передается уважение к трудящемуся человеку и его созидательному труду. Личностные компетенщии старшеклассников выражаются в осознании русского языка как национальной и культурной ценности, развивающейся системы; в переживании чувства гордости от причастности к русской культуре; в при- нятии идеи развития как основы эволюционного пути.

Урок «Наполняя будущее смыслами...» стал для учащихся этапом на пути овладения способами и приемами разных видов работы с публицистическим текстом, в том числе лингвокультурологической характеристикой; нормами русского литературного языка; навыками точно, логично и выразительно строить устное и письменное речевое произведение публицистического стиля речи заданного жанра и объема. Ученики продемонстрировали умения ставить образовательные задачи и планировать свою деятельность; эфрфективно взаимодействовать в группе, предлагать оригинальные и нестандартные решения проблемной ситуации; оценивать результаты собственной и чужой деятельности. Кроме того, выполнение заданий в дистанционном режиме способствовало развитию у учащихся информационно-коммуникационных компетенций, в частности умений работать c Google Документами и Google Таблицами, создавать видеоролики и размещать их на YouTube; участвовать в совместных видеоконференциях. Универсальный характер представленного материала обеспечен возможностью его переноса в любую образовательную среду.

\section{СПИСОК ИСТОЧНИКОВ И ЛИТЕРАТУРЫ}

1. Цыбулько, И.П. Методические рекомендации для учителей, подготовленные на основе анализа типичных ошибок участников ЕГЭ 2019 года по русскому языку. M., 2019. URL: http://fipi. $\mathrm{ru} /$ sites/default/files/document/1566978418/russkiy_yazyk_2019.pdf(дата обращения: 17.02.2020).

2. Дейкина, А.Д. Аксиологическая методика преподавания русского языка: монография. М., 2019.

3. Дейкина, А.Д., Скрябина, О.А. От готовности мысли к формированию языкового и речевого действия (о когнитивной составляющей действия) // Известия Южного федерального университета. Филологические науки. 2017. № 4. С. 206-212. 
4. Шеляпина, И.И. К вопросу о связи концепта «Труд» с константами русской культуры «Свои» и «Чужие» в отечественной публицистике // Культурология, филология, искусствоведение: актуальные проблемы современной науки. Сб. ст. по материалам XVIII междунар. науч.-практ. конф. Новосибирск, 2019. № 1 (14). С. 30-34.

5. Шеляпина, И.И. «Наполняя будущее смыслами...»: Методический комментарий к уроку развития речи в старшей школе // Аксиологическая лингвометодика: мировоззренческие и ценностные аспекты в школьном и вузовском преподавании русского языка (к юбилею профессора А.Д. Дейкиной и ее научной школы): материалы международной научно-практической конференции. В двух частях. Часть 2 / науч. ред.: А.Д. Дейкина. М., 2019. C. 361-367.

6. Левушкина, О.Н. Лингвокультурологические характеристики текста в школьном обучении русскому языку: теория и практика: дис. ... д-ра пед. наук. 13.00.02. М., 2014.

7. Соловейчик, C. О пути жизни // Пушкинские проповеди. М., 2009.

8. Труд // Философский энциклопедический словарь, 2010. URL: https://dic.academic.ru/dic.nsf/ enc_philosophy $/ 3515 / \% \mathrm{D} 0 \% \mathrm{~A} 2 \% \mathrm{D} 0 \% \mathrm{~A} 0 \% \mathrm{D} 0 \% \mathrm{~A} 3 \% \mathrm{D} 0 \% 94$ (дата обращения: 17.02.2020).

9. Атлас новых профессий [сайт]. URL: http://atlas100.ru/ (дата обращения: 27.02.2019).

10. Медиа и развлечения // Атлас новых профессий [сайт]. URL: http://atlas100.ru/catalog/mediai-razvlecheniya/?aft_2020=yes (дата обращения: 27.02.2019).

11. Богданова, Kc. Здоровое питание и повышение урожайности: Будущее в сельском хозяйстве — за микробиологией // Комсомольская правда. 2018. URL: https:/www.kp.ru/daily/26876.7/ 3919617/ (дата обращения: 27.02.2019).

12. Фирсова, K. Топ профессий будущего: мнения экспертов // Инвест - Форсайт. 2018. URL: https://www.if24.ru/professii-budushhego/ (дата обращения: 27.02.2019).

13. Огнева-Сальвони, T. В итальянской школе запустили учебный курс для старшеклассников о фешн-блогерстве // Комсомольская правда. 2019. URL: https://www.kp.ru/daily/26937/3988575/ (дата обращения: 27.02.2019).

14. Прохорова, Н. В союзе с роботом: какие специалисты будут нужны // Москва 24. 2016. URL: https://www.m24.ru/articles/professii/15042016/102799 (дата обращения: 27.02.2019).

\section{REFERENCES}

1. Atlas novyh professij [sajt], available at: http://atlas100.ru/ (accessed: 27.02.2019).

2. Bogdanova Ks. Zdorovoe pitanie i povysenie urozajnosti: Budusee v selskom hozjajstve — za mikrobiologiej, Komsomolskaja pravda, 2018, available at: https:/www.kp.ru/daily/26876.7/3 919617/ (accessed: 27.02.2019).

3. Cybulko I.P. Metodiceskie rekomendacii dlja ucitelej, podgotovlennye na osnove analiza tipicnyh osibok ucastnikov EGE 2019 goda po russkomu jazyku. Moscow, 2019, available at: http://fipi.ru/ sites/default/files/document/1566978418/russkiy_yazyk_2019.pdf (accessed: 17.02.2020).

4. Dejkina A.D. Aksiologiceskaja metodika prepodavanija russkogo jazyka: monografija. Moscow, 2019. (in Russian)

5. Dejkina A.D., Skrjabina O.A. Ot gotovnosti mysli k formirovaniju jazykovogo i recevogo dejstvija (o kognitivnoj sostavljajusej dejstvija), Izvestija Juznogo federalnogo universiteta. Filologiceskie nauki, 2017, No. 4, pp. 206-212. (in Russian)

6. Firsova K. "Top professij budusego: mnenija ekspertov", in: Invest - Forsajt, 2018, available at: https://www.if24.ru/professii-budushhego/ (accessed: 27.02.2019). 
7. Levuskina O.N. Lingvokulturologiceskie harakteristiki teksta v skolnom obucenii russkomu jazyku: teorija i praktika: ScD dissertation in Pedagogy. Moscow, 2014. (in Russian)

8. "Media i razvlecenija", in: Atlas novyh professij [sajt], available at: http://atlas100.ru/catalog/ media-i-razvlecheniya/?aft_2020=yes (accessed: 27.02.2019).

9. Ogneva-Salvoni T. V italjanskoj skole zapustili ucebnyj kurs dlja starseklassnikov o fesnblogerstve, Komsomolskaja pravda, available at: https://www.kp.ru/daily/26937/3988575/ (accessed: 27.02.2019).

10. Prohorova N. V sojuze s robotom: kakie specialisty budut nuzny, Moskva 24, 2016, available at: https:/www.m24.ru/articles/professii/15042016/102799 (accessed: 27.02.2019).

11. Sheljapina I.I. “'Napolnjaja budusee smyslami...': Metodiceskij kommentarij k uroku razvitija reci v starsej skole", in: Aksiologiceskaja lingvometodika: mirovozzrenceskie i cennostnye aspekty $v$ skolnom $i$ vuzovskom prepodavanii russkogo jazyka (k jubileju professora A.D. Dejkinoj i ee naucnoj skoly): materialy meždunarodnoj naucno-prakticeskoj konferencii. V dvuh castjah. Part 2, ed. A.D. Dejkina. Moscow, 2019, pp. 361-367. (in Russian)

12. Sheljapina I.I. 'K voprosu o svjazi koncepta 'Trud' s konstantami russkoj kultury 'Svoi' i 'Chuzhie' v otecestvennoj publicistike", in: Kulturologija, filologija, iskusstvovedenie: aktualnye problemy sovremennoj nauki, Sb. st. po materialam XVIII mezdunar. nauc.-prakt. konf. Novosibirsk, 2019, pp. 30-34. (in Russian)

13. Solovejcik P. O puti zizni. Puskinskie propovedi. Moscow, 2009. (in Russian)

14. "Trud", in: Filosofskij enciklopediceskij slovar, 2010, available at: https://dic.academic.ru/dic.nsf/ enc_philosophy $/ 3515 / \%$ D0\%A2\%D0\%A0\%D0\%A3\%D0\%94 (accessed:17.02.2020).

Шеляпина Ирина Игоревна, аспирантка, кафедра методики преподавания русского языка, Институт филологии, Московский педагогический государственный университет, shelapina@ mail.ru

Shelyapina I.I., Post-graduate Student, Department of Russian Language Teaching Methods, Institute of Philology, Moscow Pedagogical State University, shelapina@mail.ru 